\title{
Pelaksanaan Konstitusional Kewenangan Bawaslu sebagai Pengawas Pemilu dan Mengadili Sengketa Proses Pemilu
}

\section{Laundering Constitutional Implementation of Election Supervisory Agency Authority as Election Supervisor and General Election Process Dispute}

\author{
Yessinia Bela Abidin \\ Bagian Penindakan Pelanggaran Sekretariat \\ Badan Pengawas Pemilihan Umum Provinsi Sulawesi Tenggara \\ E-mail: yessiniabelaabidin@gmail.com \\ La Sensu \\ Pascasarjana Universitas Halu Oleo \\ E-mail: lasensu18@gmail.com \\ Guasman Tatawu \\ Pascasarjana Universitas Halu Oleo \\ E-mail: gtatawu@gmail.com
}

\begin{abstract}
The authority of election supervisory agency as a state institution that has two authorities at the same time, namely the authority to oversee the stages of the holding of elections and adjudicate disputes over the general election process must be by the state constitution (Constitution of the Republic of Indonesia 1945) in its implementation so as not to cause actions or decisions issued by election supervisory agency becomes a defect in authority. Related to this, attribution of election supervisory agency's existence in carrying out the functions of overseeing the election stage as well as examining, reviewing, adjudicating and adjudicating election process disputes consisting of administrative violations and election process disputes results in final and binding decisions to realize electoral overflow and jurisdiction and uphold the fairness of the election process. The results of the study show that: 1) The exercise of the authority to administer the election supervision carried out by Southeast Sulawesi election supervisory agency is by the state constitution (Constitution of the Republic of Indonesia 1945) and the electoral law in this case law number 7 of 2017 concerning general elections and regulations technical regulations implementing the authority of election supervisory agency by carrying out violation prevention functions by increasing public/public participation. 2) Executing the authority to adjudicate disputes over the general election process which consists of administrative violations of the general election and dispute over
\end{abstract}


the general election process, Southeast Sulawesi election supervisory agency has institutionally carried out this function optimally.

Keywords: Implementation; Election Overseer; Election Process Dispute

\begin{abstract}
Abstrak: Kewenangan Badan Pengawas Pemilihan Umum (Bawaslu) sebagai lembaga negara yang memiliki dua kewenangan sekaligus yaitu kewenangan mengawasi tahapan penyelenggaraan pemilihan umum dan mengadili sengketa proses pemilihan umum harus sesuai dengan konstitusi negara (Undang-Undang Dasar Negara Republik Indonesia Tahun 1945) dalam pelaksanaannya agar tidak menyebabkan tindakan atau putusan yang dikeluarkan Bawaslu menjadi cacat wewenang. Terkait hal tersebut, secara atribusi eksistensi Bawaslu dalam menjalankan fungsi penyelenggaraan pengawasan tahapan Pemilu serta memeriksa, mengkaji, mengadili dan memutus sengketa proses Pemilu yang terdiri dari pelanggaran administratif dan sengketa proses Pemilu berujung pada putusan yang final dan mengikat guna mewujudkan Pemilu yang Luber-Jurdil dan menegakkan keadilan proses Pemilu. Hasil penelitian menunjukkan bahwa: 1) Pelaksanaan wewenang penyelenggaraan pengawasan Pemilu yang dilakukan oleh Bawaslu Provinsi Sulawesi Tenggara telah sesuai dengan konstitusi negara (Undang-Undang Dasar Negara Republik Indonesia Tahun 1945) dan kaidah hukum Pemilu dalam hal ini Undang-Undang Republik Indonesia Nomor 7 Tahun 2017 tentang Pemilihan Umum dan peraturan-peraturan teknis pelaksanaan kewenangan Bawaslu dengan menjalankan fungsi-fungsi pencegahan pelanggaran dengan meningkatkan partisipasi masyarakat/publik. 2) Pelaksanaan kewenangan mengadili sengketa proses Pemilu yang terdiri dari pelanggaran administratif Pemilu dan sengketa proses Pemilu, Bawaslu Provinsi Sulawesi Tenggara secara institusional telah melaksanakan fungsi tersebut secara optimal.
\end{abstract}

Kata kunci: Pelaksanaan; Pengawas Pemilu; Sengketa Proses Pemilu

\title{
PENDAHULUAN
}

Badan Pengawas Pemilihan Umum (Bawaslu) mendapatkan dua kewenangan di saat yang bersamaan yakni kewenangan eksekutif dalam menjalankan fungsi pengawasan dan kewenangan mengadili sengketa proses Pemilu yang terdiri dari pelanggaran administratif dan sengketa proses pemilihan umum (Pemilu).

Baron de Montesquieu dalam karyanya yang berjudul L'Esprit des Lois (The Spirit of the Laws) menguraikan bahwa Montesquieu membagi kekuasaan pemerintahan dalam tiga cabang, yaitu Legislatif, Eksekutif, Yudikatif. Menurutnya, ketiga kekuasaan itu harus terpisah satu sama lain, baik mengenai tugas (fungsi) maupun mengenai alat perlengkapan (lembaga) yang menyelenggarakannya. Menurut Montesquieu, kekuatan Legislatif adalah kekuasaan membuat undang-undang, kekuatan Eksekutif meliputi penyelenggaraan undang-undang (oleh Montesquieu diutamakan tindakan di bidang 
politik luar negeri), dan kekuasaan Yudikatif adalah kekuasaan mengadili terhadap pelanggaran undang-undang (yudikatif). ${ }^{1}$

Kemudian, Sir Ivor Jennings membedakan pemisahan kekuasaan (separation of power) dalam arti material dan formal. Pemisahan kekuasaan dalam arti material ialah pemisahan kekuasaan dalam arti pembagian kekuasaan itu dipertahankan dengan tegas dalam fungsi tugas-tugas kenegaraan yang secara karakteristik memperlihatkan adanya pemisahan kekuasaan itu pada tiga badan, yakni legislatif, eksekutif, dan yudikatif. Sedangkan yang dimaksud dengan pemisahan kekuasaan dalam arti formal ialah apabila pembagian kekuasaan itu tidak dipertahankan dengan tegas. ${ }^{2}$ Robert M. McIver mengatakan bahwa pemisahan kekuasaan dalam arti material disebut dengan pemisahan kekuasaan (separation of powers), sedangkan pemisahan kekuasaan dalam arti formal disebut dengan pembagian kekuasaan (division of powers). ${ }^{3}$

Kekuasaan menggambarkan hak untuk berbuat atau tidak berbuat wewenang berarti hak dan sekaligus kewajiban (rechten en plichten). ${ }^{4}$ Menurut Philipus M. Hadjon, wewenang dan substansi merupakan landasan bagi legalitas formal. Atas dasar legalitas formal lahirlah asas praesumptio iustae causa. ${ }^{5}$ Menurut Tatiek Sri Djatmiati, dalam hal tidak terpenuhi legalitas tersebut menyebabkan cacat dalam tindakan pemerintah. Cacat wewenang mengakibatkan tindakan pemerintahan atau keputusan pemerintah menjadi batal demi hukum (nietig). Cacat prosedur tidak menyebabkan tindakan atau keputusan pemerintah menjadi batal, namun kekurangan yang ada harus dilengkapi. Cacat prosedur dapat dimohonkan pembatalan, dan bukan batal demi hukum. 6

1 Romi Librayanto, Trias Politica dalam Struktur Ketatanegaraan Indonesia, Makassar: Pukap, 2008, hlm. 152.

2 Sir Ivor Jennings, The Law and the Constitution, 4th edition, London: The English Language Book Society, 1976, hlm. 22. Lihat juga dalam Winarno Yudho et.al., Mekanisme Impeachment \& Hukum Acara Mahkamah Konstitusi, Jakarta: Pusat Penelitian dan Pengkajian, Sekretariat Jenderal dan Kepaniteraan, Mahkamah Konstitusi, Republik Indonesia bekerjasama dengan Konrad-Adenauer-Stiftung, 2005, hlm. 14.

3 Robert M. McIver, The Modern State, Oxford: Oxford University Press, 1950, hlm. 364. Lihat juga dalam Winarno Yudho et.al., Ibid.

4 Bagir Manan, Wewenang Propinsi, Kabupaten dan Kota dalam Rangka Otonomi Daerah, Makalah pada Seminar Nasional Pengembangan Wilayah dan Pengelolaan Sumber Daya Alam di Kawasan Pesisir dalam Rangka Penataan Ruang, Bandung: Fakultas Hukum Universitas Padjadjaran, 13 Mei 2000, hlm. 1. Lihat juga dalam Guasman Tatawu. "Hakekat Hukum Putusan Mahkamah Konstitusi terhadap Sengketa Pemilihan Kepala Daerah (Pilkada)”, Halu Oleo Law Review, Volume 1 Issue 2, September 2017, hlm. 150.

5 Asas praesumptio iustae causa adalah asas yang menempatkan bahwa setiap keputusan Pemerintah harus dipandang benar. Asas ini diterapkan agar dapat memberikan kepastian hukum dan hukum memberikan kepada pemerintah untuk menetapkan keputusan.

6 Philipus M Hadjon, Paulus Effendie Lotulung, H.M. Laica Marzuki, Tatiek Sri Djatmiati, dan I Gusti Ngurah Wairocana, Hukum Administrasi dan Good Governance, Jakarta: Universitas Trisakti, 2010, hlm. 95. Lihat juga dalam Guasman Tatawu, Op.Cit., hlm. 151. 
Kewenangan campur sari Bawaslu dalam menjalankan tugas dan wewenang pada Pemilihan Umum Tahun 2019 yakni sebagai pengawas penyelenggaraan Pemilu yang merupakan fungsi eksekutif dan kewenangan memutus penyelesaian sengketa proses Pemilu yang identik dengan fungsi yudikatif kontradiksi apabila merujuk pada doktrin Trias Politica bahwa kewenangan/kekuasaan (eksekutif, legislatif, yudikatif) harus dibatasi untuk menjamin tidak terjadinya kesewenang-wenangan pemegang kekuasaan dalam hal ini lembaga negara yang diberi wewenang baik dari Undang-Undang Dasar Negara Republik Indonesia Tahun 1945 atau peraturan perundang-undangan serta tidak tersebutnya secara expressive verbis dalam Undang-Undang Dasar Negara Republik Indonesia Tahun 1945 mengenai kedudukan dan fungsi Bawaslu dalam penyelenggaraan pemilihan umum sehingga akan mengakibatkan ketiadaan keberadaan (nir-eksistensi) Bawaslu sebagai lembaga pengawas penyelenggaraan Pemilu yang akan mengancam prinsip-prinsip absolut penyelenggaraan Pemilu yakni Langsung, Umum, Bebas, Rahasia, Jujur, dan Adil (Luber-Jurdil) pada setiap pelaksanaan pengawasan dan mengadili sengketa proses Pemilu.

\section{METODE PENELITIAN}

Pelaksanaan penelitian ini adalah suatu penelitian hukum yang akan mengkaji dan menganalisis pelaksanaan konstitusional kewenangan Bawaslu dalam mengawasi penyelenggaraan Pemilu dan mengadili sengketa proses Pemilu ke dalam 3 (tiga) tataran hukum, yaitu, teori hukum (rechtstheorie), filsafat hukum (rechtsfilosofie) dan dogmatik hukum (rechtsdogmatiek). Teori hukum, filsafat hukum dan dogmatik hukum kemudian diarahkan kepada praktik hukum yang menyangkut pembentukan hukum dan penerapan hukum. ${ }^{7}$

Jenis penelitian/pendekatan yang digunakan oleh penulis adalah penelitian hukum normative empirik. Penelitian hukum normatif menurut Peter Mahmud Marzuki yaitu penelitian hukum yang dilakukan dengan pendekatan undang-undang (statute approach), pendekatan kasus (case approach), pendekatan historis (historical approach), pendekatan komparatif (comparative approach), dan pendekatan konseptual (conceptual approach). ${ }^{8}$ Sedangkan normative empiris, yakni penelitian yuridis dilakukan dengan cara meneliti bahan pustaka yang merupakan data primer dan juga disebut penelitian

\footnotetext{
Bruggink dalam Arief Sidharta, Refleksi Tentang Hukum, Bandung: Citra Aditya Bhakti, 1999, hlm. 65.

Peter Mahmud Marzuki, Penelitian Hukum, Jakarta: Kencana Prenada Media Group, 2005, hlm. 93.
} 
kepustakaan. Penelitian hukum empiris dilakukan dengan cara meneliti pelaksanaan kewenangan Bawaslu yang merupakan bahan hukum sekunder.

\section{ANALISIS DAN PEMBAHASAN}

\section{Pelaksanaan Konstitusional Kewenangan Bawaslu sebagai Pengawas Pemilu}

Konstitusi adalah kumpulan asas-asas yang mengatur dan menetapkan kekuasaan dan pemerintah, hak-hak yang diperintah, dan hubungan antara keduanya atau antara pemerintah dengan yang diperintah. Konstitusi dipergunakan untuk menggambarkan keseluruhan sistem ketatanegaraan suatu negara, yang merupakan kumpulan peraturan yang menetapkan dan mengatur atau menentukan pemerintah. Konstitusionalisme merupakan komponen integral dari pemerintahan demokratis. Di Indonesia UndangUndang Dasar Negara Republik Indonesia Tahun 1945 merupakan ide konstitusionalisme dalam kehidupan bernegara

Pada Pasal 22E Undang-Undang Dasar Negara Republik Indonesia Tahun 1945 sendiri tidak hanya mengatur dasar yuridis mekanisme demokrasi prosedural (Pemilu), tetapi juga mengatur apa dan siapa yang diberi kewenangan untuk menjalankan Pemilu. Sebab, untuk memenuhi prinsip-prinsip Pemilu yang Luber dan Jurdil, idealnya harus dijalankan oleh suatu lembaga penyelenggara yang didesain untuk menyelenggarakan suatu Pemilihan umum. Oleh Pasal 22E ayat (5) Undang-Undang Dasar Negara Republik Indonesia Tahun 1945, pembentuk Undang-Undang Dasar Negara Republik Indonesia Tahun 1945 menghendaki dan memerintahkan pembentukan “...suatu komisi pemilihan umum".

Pasal 22E ayat (5) Undang-Undang Dasar Negara Republik Indonesia Tahun 1945 merupakan akar konstitusionalisme pembentukan lembaga penyelenggara Pemilu sebagai suatu cabang kekuasaan di luar 3 (tiga) cabang kekuasaan konvensional. ${ }^{9}$ Rumusan Pasal 22E ayat (5) Undang-Undang Dasar Negara Republik Indonesia Tahun 1945 memberikan petunjuk bahwa pemilihan umum mestinya dijalankan oleh "suatu komisi pemilihan umum". Frasa "suatu komisi pemilihan umum" yang ditulis dengan huruf kecil (bukan huruf kapital) menunjukkan perlunya sebuah badan atau lembaga-lembaga yang difungsikan sebagai penyelenggara Pemilu. Landasan argumentasi penulis merujuk pada pendapat Mahkamah Konstitusi melalui Putusan Mahkamah Konstitusi Nomor 81-PUU-IX2011 yang berbunyi:

$9 \quad$ Eksekutif, Legislatif, dan Yudikatif. 
"Bahwa untuk menjamin terselenggaranya pemilihan umum yang luber dan jurdil, Pasal 22E ayat (5) Undang-Undang Dasar Negara Republik Indonesia Tahun 1945 menentukan bahwa, "Pemilihan umum diselenggarakan oleh suatu komisi pemilihan umum yang bersifat nasional, tetap dan mandiri". Kalimat "suatu komisi pemilihan umum" dalam Undang-Undang Dasar Negara Republik Indonesia Tahun 1945 tidak merujuk kepada sebuah nama institusi, akan tetapi menunjuk pada fungsi penyelenggaraan pemilihan umum yang bersifat nasional, tetap dan mandiri."

Ketentuan Pasal 22E ayat (5) Undang-Undang Dasar Negara Republik Indonesia Tahun 1945 pun juga tidak berdiri sendiri dan terpisah dengan rumusan dalam Pasal 22E ayat (6) Undang-Undang Dasar Negara Republik Indonesia Tahun 1945 yang berbunyi "ketentuan lebih lanjut tentang pemilihan umum diatur dengan undang-undang". Frasa "diatur dengan undang-undang" menunjukkan adanya kehendak pembentuk UndangUndang Dasar Negara Republik Indonesia Tahun 1945 untuk memberikan kewenangan atributif pelaksana kekuasaan pembentuk undang-undang dalam hal ini kekuasaan legislatif (dalam hal ini adalah Dewan Perwakilan Rakyat) untuk menerjemahkan sekaligus memberikan bentuk lembaga atau badan-badan penyelenggara Pemilu seperti apa yang akan difungsikan sebagai penyelenggara pemilu. Dengan adanya atribusi kewenangan yang diberikan kepada Dewan Perwakilan Rakyat untuk memilih, menentukan, membentuk, dan melegalkan lembaga-lembaga penyelenggara Pemilu melalui produk hukum berbentuk Undang-undang, maka sepatutnya pemberian nama, bentuk, dan jenis kewenangan penyelenggara pemilu diatur melalui undang-undang.

Keberadaan lembaga penyelenggara Pemilu dalam produk hukum berbentuk Undang-undang dapat dilihat secara lugas dalam batang tubuh Pasal 1 angka 7 UndangUndang Republik Indonesia Nomor 7 Tahun 2017 tentang Pemilihan Umum yang menyebutkan bahwa:

"Penyelenggara Pemilu adalah lembaga yang menyelenggarakan pemilu yang terdiri atas Komisi Pemilihan Umum, Badan Pengawas Pemilu, dan Dewan Kehormatan Penyelenggara Pemilu sebagai satu kesatuan fungsi Penyelenggaraan Pemilu anggota Dewan Perwakilan Rakyat, anggota Dewan Perwakilan Daerah, Presiden dan Wakil Presiden, dan untuk memilih anggota Dewan Perwakilan Rakyat Daerah secara langsung oleh rakyat."

Berangkat dari pengertian Pasal 1 angka 7 Undang-Undang Republik Indonesia Nomor 7 Tahun 2017 tentang Pemilihan Umum, maka dapat dipastikan bahwa lembaga atau badan penyelenggara pemilu yang dikehendaki oleh pembentuk undang-undang sebagai tindaklanjut atas perintah atributif pembentuk Undang-Undang Dasar Negara 
Republik Indonesia Tahun 1945 adalah Komisi Pemilihan Umum, Badan Pengawas Pemilu, dan Dewan Kehormatan Penyelenggara Pemilu. Dengan demikian, struktur dan kedudukan konstitusionalitas lembaga penyelenggara pemilu yang ditarik dari Pasal 22E UndangUndang Dasar Negara Republik Indonesia Tahun 1945 hanya mengenal 3 (tiga) struktur lembaga penyelenggara Pemilu sebagaimana disebutkan dalam Undang-Undang Republik Indonesia Nomor 7 Tahun 2017 tentang Pemilihan Umum.

Sekalipun berdasarkan fungsi pembentukannya Bawaslu dikelompokkan sebagai lembaga negara penunjang (State Auxiliary Agencies) karena tidak disebutkan secara expressive-verbis dalam batang tubuh Undang-Undang Dasar Negara Republik Indonesia Tahun 1945, namun berdasarkan sumber pembentukannya, Bawaslu dibentuk berdasarkan kehendak pembentuk Undang-Undang Dasar Negara Republik Indonesia Tahun 1945 atau bersumber dari ketentuan Pasal 22E ayat (5) Undang-Undang Dasar Negara Republik Indonesia Tahun 1945 (vide Putusan Mahkamah Konstitusi Nomor 81PUU-IX-2011). Maka dari itu, secara yuridis, Bawaslu memiliki dasar hukum konstitusional sebagai lembaga penyelenggara pemilu yang didesain sebagai penyelenggara pengawasan pemilu.

Dalam melaksanakan kewenangan pengawasan penyelenggaraan Pemilu Bawaslu Provinsi Sulawesi Tenggara melakukan kegiatan-kegiatan yang menggambarkan bentuk pelaksanaan fungsi pengawasan Bawaslu sebagai lembaga yang diberi wewenang menurut Pasal 89, Pasal 94 ayat (1) dan Pasal 98 ayat (1) Undang-Undang Republik Indonesia Nomor 7 Tahun 2017 tentang Pemilihan Umum, Bawaslu memiliki tugas melakukan pencegahan pelanggaran dan sengketa proses Pemilu dengan meningkatkan partisipasi masyarakat dalam Pengawasan Pemilu sesuai dengan tingkatannya. Kegiatan pengawasan berbasis IT (information technology/teknologi Informasi) melalui Gowaslu yang merupakan respons Bawaslu dalam menjalankan kewenangan pengawasan dengan mengikuti tren IT yang berkembang dimasyarakat milenial. Aplikasi Gowaslu ini memudahkan masyarakat dalam melaporkan dugaan baik pelanggaran dan sengketa selama tahapan penyelenggaraan Pemilu. Kemudahan instrumen dengan pelaporan online memakai sistem operasi berbasis Android yang dapat mengakomodasi masyarakat yang memiliki keterbatasan jarak untuk dapat memberikan partisipasinya dalam pengawasan Pemilu.

Kemudian kegiatan pojok pengawasan merupakan pelaksanaan kewenangan mengawasi yang dilaksanakan oleh Bawaslu Provinsi Sulawesi Tenggara sesuai dengan 
Pasal 97 huruf f Undang-Undang Republik Indonesia Nomor 7 Tahun 2017 tentang Pemilihan Umum, yang menyatakan Bawaslu bertugas mengelola, memelihara, dan merawat arsip....". Hasil pengawasan yang telah diarsipkan dengan baik akan menjadi bahan evaluasi pengawasan pemilu di wilayah provinsi yang merupakan tugas Bawaslu sesuai Pasal 97 huruf h Undang-Undang Republik Indonesia Nomor 7 Tahun 2017 tentang Pemilihan Umum. Pembentukan pojok pengawasan sejalan dengan pelaksanaan tugas Bawaslu yang terdapat Pasal 440 angka 1 Undang-Undang Republik Indonesia Nomor 7 Tahun 2017 tentang Pemilihan Umum, bahwa Bawaslu memberikan akses informasi yang disediakan oleh Bawaslu, Bawaslu Provinsi dan Bawaslu Provinsi Kab/Kota.

Pelaksanaan kewenangan mengawasi oleh Bawaslu dengan kegiatan Forum Warga, merupakan bentuk dari upaya Bawaslu Provinsi Sulawesi Tenggara dalam menjalin koordinasi yang masif dengan masyarakat sipil untuk mengawasi setiap tahapan penyelenggaraan Pemilu. Kemudian kegiatan Saka Adhyasta Pemilu dan Gerakan Partisipatif Pengawas Pemilu merupakan upaya Bawaslu Provinsi Sulawesi Tenggara dalam meningkatkan partisipatif masyarakat usia muda untuk sadar dan ikut andil dalam penyelenggaraan Pemilu yang Luber Jurdil sesuai dengan Pasal 2 Undang-Undang Republik Indonesia Nomor 7 Tahun 2017 tentang Pemilihan Umum.

\section{Pelaksanaan Konstitusional Kewenangan Bawaslu Dalam Mengadili Sengketa Pemilu}

Kewenangan mengadili sengketa Pemilu yang dilekatkan pada Bawaslu merupakan kewenangan yang sifatnya atributif sebab kewenangan untuk memeriksa, mengkaji, mengadili, dan memutus pelanggaran-pelanggaran pemilu (administratif pemilu dan penyelesaian sengketa proses pemilu) bersumber dari Pasal 94 Undang-Undang Republik Indonesia Nomor 7 Tahun 2017 tentang Pemilihan Umum.

Selain itu, tafsir konstitusional terhadap kewenangan mengadili sengketa Pemilu oleh Bawaslu juga dikuatkan melalui Putusan Mahkamah Konstitusi Nomor 31/PUUXVI/2018 Petitum keenam halaman 48-49 yang memberikan penguatan bahwa frasa 'rekomendasi' terhadap pelanggaran administratif pemilu yang dilekatkan pada Bawaslu melalui rumusan Pasal 286 ayat (2) Undang-Undang Republik Indonesia Nomor 7 Tahun 2017 tentang Pemilihan Umum harus dimaknai sebagai produk hukum berbentuk Putusan. Ratio-legis hakim Mahkamah Konstitusi dalam Putusan Mahkamah Konstitusi Nomor 31/PUU-XVI/2018, hendak memberi penguatan terhadap lembaga Bawaslu yang tadinya 
secara redaksional hasil penanganan pelanggaran administratif berbentuk rekomendasi diubah menjadi bentuk putusan. Artinya bahwa dengan memberikan kuasa kepada Bawaslu untuk menerbitkan produk hukum berbentuk putusan, kewenangan mengadili yang dilekatkan pada Bawaslu hendak ditegaskan oleh Mahkamah Konstitusi dengan memandang penempatan kewenangan mengadili sengketa proses Pemilu yang berada pada Bawaslu merupakan kewenangan yang sudah tepat adanya, atau sudah seharusnya dan tidak menjadi sebuah pertentangan. Pun seandainya, kuasa produk hukum berupa putusan tadi tidak dimiliki oleh Bawaslu, maka putusan yang merupakan produk hukum mengadili sengketa proses Pemilu tidak boleh pula dimiliki oleh Bawaslu. Akan tetapi, berdasarkan Putusan Mahkamah Konstitusi Nomor 31/PUU-XVI/2018, Mahkamah Konstitusi telah memberikan penguatan kewenangan melalui tafsir Konstitusionalitas wewenang Bawaslu dalam menjalankan fungsi-fungsi kewenangan mengadili sengketa proses Pemilu sebagaimana pula linear dengan Pasal 94 Undang-Undang Republik Indonesia Nomor 7 Tahun 2017 tentang Pemilihan Umum.

Berkaitan dengan konstitusionalitas kewenangan mengadili sengketa proses Pemilu yang dilekatkan pada Bawaslu, jika ditelisik ke dalam struktur norma di UndangUndang Republik Indonesia Nomor 7 Tahun 2017 tentang Pemilihan Umum, pembentuk Undang-Undang Republik Indonesia Nomor 7 Tahun 2017 tentang Pemilihan Umum juga menghendaki Bawaslu tidak sekedar menjadi lembaga pengawas (supervisory bodies), melainkan pula di-setting menjadi lembaga yang memiliki kewenangan memeriksa, mengadili dan memutus sengketa proses Pemilu. Pembenaran hukum penulis ini dapat dilacak dalam norma hukum Pasal 94 ayat (2) jo. ayat (3) Undang-Undang Republik Indonesia Nomor 7 Tahun 2017 tentang Pemilihan Umum yang menugaskan Bawaslu untuk menerima, memeriksa, mengkaji, dan memutus pelanggaran administrasi Pemilu dan memutus penyelesaian sengketa proses Pemilu. Pasal 93 huruf b Undang-Undang Republik Indonesia Nomor 7 Tahun 2017 tentang Pemilihan Umum, Bawaslu bertugas melakukan pencegahan dan penindakan terhadap pelanggaran pemilu dan sengketa proses Pemilu. Sedangkan yang dimaksud dengan Bawaslu berdasarkan Pasal 1 angka 17 Undang-Undang Republik Indonesia Nomor 7 Tahun 2017 tentang Pemilihan Umum, Bawaslu adalah lembaga Penyelenggara Pemilu yang mengawasi Penyelenggaraan Pemilu di seluruh wilayah negara Kesatuan Republik Indonesia. Dengan demikian seketika tahapan penyelenggaraan pemilihan umum berjalan Bawaslu hadir sebagai salah satu institusi yang menyelenggarakan fungsi pengawasan (Pasal 89 Undang-Undang Republik 
Indonesia Nomor 7 Tahun 2017 tentang Pemilihan Umum) dan fungsi kuasi mengadili sengketa proses Pemilu (Pasal 94 dan 95 Undang-Undang Republik Indonesia Nomor 7 Tahun 2017 tentang Pemilihan Umum) sebagaimana yang dimaksud Pasal 22E UndangUndang Dasar Negara Republik Indonesia Tahun 1945. Dengan demikian dasar hukum kewenangan Bawaslu sebagai pengawas Pemilu termuat pada Pasal 22E Undang-Undang Dasar Negara Republik Indonesia Tahun 1945, Putusan Mahkamah Konstitusi Nomor 31/PUU-XVI/2018 dan Undang-Undang Republik Indonesia Nomor 7 Tahun 2017 tentang Pemilihan Umum.

Kedudukan hukum Bawaslu dalam memeriksa dan memutus sengketa proses Pemilu dan pelanggaran administrasi Pemilu termaktub pada Pasal 94 ayat 2 huruf d Undang-Undang Republik Indonesia Nomor 7 Tahun 2017 tentang Pemilihan Umum, dalam melakukan penindakan pelanggaran Pemilu, Bawaslu bertugas "memutus pelanggaran administrasi Pemilu". Pasal 94 ayat (3) huruf d dan e, dalam melakukan penindakan sengketa proses Pemilu, Bawaslu bertugas "melakukan proses adjudikasi sengketa proses Pemilu; memutus penyelesaian sengketa proses Pemilu”. Pasal 95 huruf a dan huruf d Undang-Undang Republik Indonesia Nomor 7 Tahun 2017 tentang Pemilihan Umum, Bawaslu berwenang "memeriksa, mengkaji, dan memutus pelanggaran administrasi Pemilu dan menerima, memeriksa, memediasi atau mengajudikasi dan memutus penyelesaian sengketa proses Pemilu.

Sebagai tindak lanjut dari Putusan Mahkamah Konstitusi Nomor 31/PUUXVI/2018 maka disusunlah Peraturan Badan Pengawas Pemilihan Umum Republik Indonesia Nomor 27 Tahun 2018 tentang Perubahan Kedua Atas Peraturan Badan Pengawas Pemilihan Umum Republik Indonesia Nomor 18 Tahun 2017 tentang Tata Cara Penyelesaian Sengketa Proses Pemilihan Umum secara eksplisit dan lex specialis menguraikan tata cara penyelesaian sengketa proses pemilu, Peraturan Badan Pengawas Pemilihan Umum Republik Indonesia Nomor 7 Tahun 2018 tentang Penanganan Temuan dan Laporan Pelanggaran Pemilihan Umum dan Peraturan Badan Pengawas Pemilihan Umum Republik Indonesia Nomor 8 Tahun 2018 tentang Penyelesaian Pelanggaran Administratif Pemilihan Umum.

Secara atributif Bawaslu diberikan kewenangan oleh Undang-Undang untuk mengadili sengketa proses Pemilu. Pasal 94 ayat (3) dan ayat (4) Undang-Undang Republik Indonesia Nomor 7 Tahun 2017 tentang Pemilihan Umum, guna melakukan pencegahan pelanggaran Pemilu dan pencegahan sengketa proses Pemilu sebagaimana 
Pasal 93 huruf b Undang-Undang Republik Indonesia Nomor 7 Tahun 2017 tentang Pemilihan Umum, Bawaslu bertugas melakukan proses adjudikasi sengketa proses Pemilu; dan memutus penyelesaian sengketa proses Pemilu.

\section{KESIMPULAN}

Berdasarkan hasil analisis dan kajian pada pelaksanaan konstitusional kewenangan Bawaslu mengawasi penyelenggaraan Pemilu dan mengadili sengketa Pemilu, maka dapat ditarik kesimpulan pelaksanaan wewenang penyelenggaraan pengawasan Pemilu yang dilakukan oleh Bawaslu Provinsi Sulawesi Tenggara telah sesuai dengan Undang-Undang Dasar Negara Republik Indonesia Tahun 1945 dan kaidah hukum Pemilu dalam hal ini menurut Undang-Undang Republik Indonesia Nomor 7 Tahun 2017 tentang Pemilihan Umum. Di samping itu, Bawaslu Provinsi Sulawesi Tenggara juga telah melakukan fungsifungsi pencegahan pelanggaran dengan meningkatkan partisipasi masyarakat/publik melalui program-program pengawasan partisipatif pemilu yang melibatkan pemilih untuk ikut serta bersama Bawaslu mengawasi proses penyelenggaraan pemilu dan pelaksanaan kewenangan mengadili sengketa Pemilu dalam hal ini pelanggaran administratif Pemilu dan sengketa proses Pemilu, Bawaslu berdasar pada tujuan untuk mewujudkan Pemilu yang langsung, umum, bebas, rahasia, jujur dan adil, Bawaslu Provinsi Sulawesi Tenggara secara institusional telah melaksanakan fungsi tersebut secara optimal.

\section{Daftar Pustaka}

\section{Buku}

Hadjon, Philipus M., Paulus Effendie Lotulung, H.M. Laica Marzuki, Tatiek Sri Djatmiati, dan I Gusti Ngurah Wairocana, Hukum Administrasi dan Good Governance, Jakarta: Universitas Trisakti, 2010.

Jennings, Sir Ivor, The Law and the Constitution, 4th edition, London: The English Language Book Society, 1976.

Librayanto, Romi, Trias Politica dalam Struktur Ketatanegaraan Indonesia, Makassar: Pukap, 2008.

Marzuki, Peter Mahmud, Penelitian Hukum, Jakarta: Kencana Prenada Media Group, 2005.

McIver, Robert M., The Modern State, Oxford: Oxford University Press, 1950.

Sidharta, Arief, Refleksi Tentang Hukum, Bandung: Citra Aditya Bhakti, 1999. 
Yudho, Winarno et.al., Mekanisme Impeachment \& Hukum Acara Mahkamah Konstitusi, Jakarta: Pusat Penelitian dan Pengkajian, Sekretariat Jenderal dan Kepaniteraan, Mahkamah Konstitusi, Republik Indonesia bekerjasama dengan KonradAdenauer-Stiftung, 2005.

\section{Jurnal dan Makalah}

Manan, Bagir, Wewenang Propinsi, Kabupaten dan Kota dalam Rangka Otonomi Daerah, Makalah pada Seminar Nasional Pengembangan Wilayah dan Pengelolaan Sumber Daya Alam di Kawasan Pesisir dalam Rangka Penataan Ruang, Bandung: Fakultas Hukum Universitas Padjadjaran, 13 Mei 2000.

Tatawu, Guasman, "Hakekat Hukum Putusan Mahkamah Konstitusi terhadap Sengketa Pemilihan Kepala Daerah (Pilkada)", Halu Oleo Law Review, Volume 1 Issue 2, September 2017.

\section{Peraturan Perundang-undangan}

Undang-Undang Dasar Negara Republik Indonesia Tahun 1945.

Undang-Undang Republik Indonesia Nomor 7 Tahun 2017 tentang Pemilihan Umum (Lembaran Negara Republik Indonesia Tahun 2017 Nomor 182, Tambahan Lembaran Negara Republik Indonesia Nomor 6109).

Putusan Mahkamah Konstitusi Nomor 81/PUU-XI/2011.

Putusan Mahkamah Konstitusi Nomor 311/PUU-XVI/2018.

Peraturan Badan Pengawas Pemilihan Umum Republik Indonesia Nomor 18 Tahun 2017 tentang Tata Cara Penyelesaian Sengketa Proses Pemilihan Umum (Berita Negara Republik Indonesia Tahun 2017 Nomor 1826).

Peraturan Badan Pengawas Pemilihan Umum Republik Indonesia Nomor 7 Tahun 2018 tentang Penanganan Temuan dan Laporan Pelanggaran Pemilihan Umum (Berita Negara Republik Indonesia Tahun 2018 Nomor 324).

Peraturan Badan Pengawas Pemilihan Umum Republik Indonesia Nomor 8 Tahun 2018 tentang Penyelesaian Pelanggaran Administratif Pemilihan Umum (Berita Negara Republik Indonesia Tahun 2018 Nomor 325).

Peraturan Badan Pengawas Pemilihan Umum Republik Indonesia Nomor 27 Tahun 2018 tentang Perubahan Kedua Atas Peraturan Badan Pengawas Pemilihan Umum Republik Indonesia Nomor 18 Tahun 2017 tentang Tata Cara Penyelesaian 
Sengketa Proses Pemilihan Umum (Berita Negara Republik Indonesia Tahun 2018 Nomor 1098). 